\title{
Mixture Experiment Model for Predicting the Static Modulus of Elasticity of Laterite-Quarry Dust Concrete
}

\author{
Ngwu, Chukwuemeka ${ }^{1}$, Orji, Solomon Emeka ${ }^{2}$, Onoh, Felix Emenike \\ ${ }^{1}$ Department of Quantity Surveying, Nnamdi Azikiwe University, Anambra, Nigeria. \\ ${ }^{2}$ Department of Building, Enugu State University of Science and Technology, Enugu, Nigeria. \\ ${ }^{3}$ Department of Quantity Surveying, Enugu State University of Science and Technology, Enugu, Nigeria.
}

\begin{abstract}
Static modulus of elasticity of concrete is an important structural property of concrete. However, there is no consensus on the ideal methodology for the characterization or estimation of the property, which has led to specifying a minimum value to be met by designers. This paper developed a model for predicting the 28th day static modulus of elasticity of laterite-quarry dust concrete using $[5,2]$ extreme vertices design. The model was formulated using existing data and were validated using the p-value, $F$ statistics and normal probability plot. The static modulus of elasticity were determined as a function of the compressive strength and density of the concrete cubes and a second degree polynomial was fitted to the data of the static modulus of elasticity. Several mix proportions were generated and converted to ratios and their static modulus of elasticity were obtained using the developed model. The minimum and maximum static modulus of elasticity predictable by the model are $18.51(G P a)$ and $28.87(G P a)$. The static modulus of elasticity of laterite-quarry dust concrete for both domestic and commercial construction work can be predicted using this model.
\end{abstract}

Keywords: Model, Static Modulus of Elasticity, Laterite-quarry dust concrete, Extreme Vertices Design.

\section{INTRODUCTION}

Concrete is a composite and versatile material in which the aggregates are bonded with cementitious material. It is flexible to handle and can be molded into any shape. Partial or full replacement of river sand in concrete production is becoming a norm in Nigeria as it has been shown by many researchers to improve the structural properties of concrete. Laterite-quarry dust concrete according to [21] is the mixture of cement, water, laterite, quarry dust and coarse aggregate in proper proportion to achieve a desired property of concrete. The importance of mixture experiment and model formulation for predictions in the construction industry cannot be overemphasized. This can be seen in the works of $[21,22,25,18,26,27,31,28,2,29,12,30,14$ and 4].

It is evident that the most important property of concrete is the compressive strength, however, another property that is also important is the static modulus of elasticity. [24] Believes that there is no consensus on the ideal methodology for the characterization or estimation of the static modulus of elasticity of concrete, which has led to specifying a minimum value to be met by designers. This context has led to the disagreement among the structural designers, builders, concrete suppliers and testing laboratories, pointing out to the urgent need to advance the usual methodology and standard. Structural designers usually estimate the static modulus of elasticity of concrete employing formula that associates the static modulus of elasticity with the compressive strength. These are empirical formulas and they depend on the classification of concrete under evaluation. However, these formulas must be used with reservation and caution because compressive strength and modulus of elasticity are distinct properties that are differently influenced by the concrete variables $[15,16]$.

[21] Developed models for predicting the compressive strength and cost of laterite-quarry dust concrete using the extreme vertices design. The components were expressed in real ratios. To this effect, the objective of this research is to develop a reliable model for predicting the $28^{\text {th }}$ day static modulus of elasticity of laterite-quarry dust concrete using the extreme vertices design. 


\section{MIXTURE EXPERIMENT AND MODEL FORMATION}

Mixture experiment is one in which the response is dependent on only the proportions of the constituent materials [11]. The constituents of the mixture can either be measured by volume or mass. The constituent proportions must be constrained to sum to 1 and none must have a negative value. The statement above can be stated mathematically as:

$$
\sum_{i=1}^{q} x_{i}=x_{1}+x_{2}+x_{3}+x_{4} \ldots+x_{q}=1.0
$$

Where, $i=1,2,3 \ldots \ldots \ldots$

$\mathrm{q}=$ the number of mixture component

$x_{i}=$ proportion of constituent $i$

If the response is denoted by y and $x_{1}, x_{2}, x_{3}, x_{4}$, and $x_{5}$ are the constituents of the mixture (water, cement, laterite, quarry dust, and crushed rock), then the equation can be represented as:

$$
y=f\left(x_{1}, x_{2}, x_{3}, x_{4}, x_{5}\right)
$$

A general form of a polynomial of degree $\mathrm{M}$, in $\mathrm{q}$ variables is given by [1] as;

$\hat{y}=b_{0}+\sum_{1 \leq i \leq q} b i x_{i}+\sum_{1 \leq i \leq j \leq q} b i j x_{i} j+\sum_{1 \leq i \leq j \leq k \leq q} b i j k x_{i} x_{j} x_{k}+\sum b i_{1} i_{2} i_{n} x i_{1} x i_{2} x i_{m}$

When the number of components, $q=5$, and $\mathrm{M}=2$, the number of terms will be fifteen (15) and equation (3) can be written as:

$\hat{y}=$

$\beta_{1} x_{1}+\beta_{2} x_{2}+\beta_{3} x_{3}+\beta_{4} x_{4}+\beta_{5} x_{5}+\beta_{12} x_{1} x_{2}+\beta_{13} x_{1} x_{3}+\beta_{14} x_{1} x_{4}+$

$\beta_{15} x_{1} x_{5}+\beta_{23} x_{2} x_{3}+\beta_{24} x_{2} x_{4}+\beta_{25} x_{2} x_{5}+\beta_{34} x_{3} x_{4}+\beta_{35} x_{3} x_{5}+\beta_{45} x_{4} x_{5}$

Extreme vertices design covers a sub-portion within the simplex. It is used when components are restricted to lower $\mathrm{L}_{i}$ and upper $\mathrm{U}_{i}$ bounds or when linear constraints are added to several components. In a restricted mixture experiment, all components do not take values between 0 , to 1 , some or all of the components lie between some lower $\left(\mathrm{L}_{i}\right)$ and upper $\left(\mathrm{U}_{i}\right)$ bound [11]. With q, components, the constants are written as;

$$
0 \leq \mathrm{L}_{\mathrm{i}} \leq \mathrm{X}_{\mathrm{i}} \leq \mathrm{U}_{\mathrm{i}} \leq 1, \quad i=1,2 \ldots \mathrm{q}
$$

The design point's location on the boundaries of the region that are chosen depends on the degree of the equation to be used to model the surface over the region. However, it is important to know that the upper - and lower - bound constraints on the $X_{i}$ must be consistent before any further analysis.

\section{MATERIALS AND METHODS}

The primary data used in this work were taken from a previous study by [21] who developed an extreme vertices models for predicting the $28^{\text {th }}$ day compressive strength and cost of laterite-quarry dust concrete. The material components were; Water, Ordinary Portland Cement, Laterite, Quarry dust and Crushed rock. Potable water conforming to the specification of [6] was used for both specimen preparation and curing, and it was sourced from $9^{\text {th }}$ mile Enugu State, Nigeria. Ordinary Portland cement of grade 42.5 which conforms to [17] was used for all the tests. Laterite was obtained from Umuchigbo community in Iji-Nike, Enugu East Local Government Area of Enugu State, Nigeria while quarry dust and crushed rock were obtained from the quarry site of Jinziang quarry (Nigeria) company limited in Ezillo, Ishielu Local Government Area of Ebonyi State. Physical property tests were conducted on the laterite and quarry dust and several trial mixes of concrete were carried out to determine the lower $\left(\mathrm{L}_{\mathrm{i}}\right)$ and upper bound $\left(\mathrm{U}_{\mathrm{i}}\right)$ of each component using ratios 1:1:1.5, 1:1:2, 1:1.5:3, 1:2:4, and 1:3:6. River sand was replaced with a maximum of $40 \%$ laterite and $60 \%$ quarry dust in the trial mixes. Table 1 show bound of the five mixture components. 
International Journal of Engineering Research And Advanced Technology, Vol.7 (5), May -2021

Table 1: Bounds of the Five Mixture Components.

\begin{tabular}{|l|c|c|c|c|c|}
\hline & Water & Cement & Laterite & Quarry dust & Coarse aggregate \\
\cline { 2 - 6 } Lower bound & 0.100 & 0.140 & 0.020 & 0.130 & 0.430 \\
\hline Upper bound & 0.135 & 0.250 & 0.130 & 0.260 & 0.500 \\
\hline
\end{tabular}

Source: Orji, Anya and Ngwu (2020).

The set constraints are as follows:

Water $=0.100 \leq X_{1} \leq 0.135$, Cement $=0.140 \leq X_{2} \leq 0.250$, Laterite $=0.020 \leq X_{3} \leq 0.130$, Quarry dust $=0.130 \leq X_{4} \leq 0.260$, Coarse aggregate $=0.430 \leq \mathrm{X}_{5} \leq 0.500$.

The design matrix consisted of fifteen (15) design points and seven (7) check points with replications of the vertices and the centroid, given a total of twenty eight (28) runs. Eighty four (84) numbers of laterite-quarry dust concrete cubes of 150mm were prepared in accordance to [7] and tested for their compressive strength after 28 days of curing in accordance to [5] using controls wizard basic testing machine with a testing capacity of $2000 \mathrm{kN}$. The machine conforms to the requirement of [8]. The results of the compressive strength test were used to develop the model equation for predicting the static modulus of elasticity of laterite-quarry dust concrete. The static modulus of elasticity of the cubes were determined as a function of the compressive strength and density. A second degree polynomial was fitted to the data of the static modulus of elasticity using Minitab 17. Sequential F test ( $\rho$-value) was carried out to fit linear and quadratic models to the static modulus of elasticity result and the chosen model was the highest order model with significant terms. This was done using Analysis of variance (ANOVA). A $\rho$-value of less than 0.05 indicates a significant term. Summary statistics (R-square, Adjusted R squared, PRESS, and the standard error) for each model coefficient were also determined. Adequacy of the model was also tested using the normal probability plots at $95 \%$ confidence limit. The modulus of elasticity relates the relationship between the applied stresses and the strain they cause. It has a direct relationship with the compressive strength. It increases as the compressive strength increases. The static modulus of elasticity of the cubes were determined using Equation 6 [10].

$E_{s} \quad=\quad 1.7 \rho^{2} F_{c}^{0.33} \times 10^{-6}$

Where:

$E_{s} \quad=\quad$ Static modulus of elasticity

$\rho \quad=\quad$ Density

$F_{c} \quad=\quad$ Compressive strength

\section{RESULTS AND DISCUSSIONS}

The results of the physical property test of laterite and quarry dust is presented in Tables 2 , while the design matrix components in real ratios and the average compressive strength test result is shown in Table 3. The design matrix components in real ratios and the average static modulus of elasticity is presented in Table 4.

Table 2: Physical Properties of Laterite and Quarry Dust.

\begin{tabular}{|l|l|l|}
\hline \multicolumn{1}{|c|}{ Property } & \multicolumn{1}{|c|}{ Laterite } & \multicolumn{1}{|c|}{ Quarry dust } \\
\hline Bulk density $\left(\mathrm{kg} / \mathrm{m}^{3}\right)$ & 1240 & 1695 \\
\hline Specific gravity & 2.60 & 2.79 \\
\hline Fineness Modulus & 3.03 & 2.74 \\
\hline
\end{tabular}

Source: Orji, Anya and Ngwu (2020).). 
Table 3: (5, 2) Design Matrix Components in Real Ratios and the Average Compressive Strength Results

\begin{tabular}{|c|c|c|c|c|c|c|c|}
\hline $\begin{array}{c}\text { Run } \\
\text { Order }\end{array}$ & $\begin{array}{c}\text { Std } \\
\text { Order }\end{array}$ & Water & Cement & Laterite & $\begin{array}{c}\text { Quarry } \\
\text { Dust }\end{array}$ & $\begin{array}{c}\text { Coarse } \\
\text { Aggregate }\end{array}$ & $A v \cdot f_{c}\left(N m m^{2}\right)$ \\
\hline 1 & 93 & 0.964286 & 1 & 0.142857 & 1.464286 & 3.571429 & 7.19 \\
\hline 2 & 105 & 0.964286 & 1 & 0.25 & 1.857143 & 3.071429 & 6.81 \\
\hline 3 & 10 & 0.526316 & 1 & 0.105263 & 1.368421 & 2.263158 & 19.27 \\
\hline 4 & 6 & 0.714286 & 1 & 0.928571 & 1.428571 & 3.071429 & 12.00 \\
\hline 5 & 1 & 0.714286 & 1 & 0.142857 & 1.714286 & 3.571429 & 10.00 \\
\hline 6 & 21 & 0.771429 & 1 & 0.742857 & 0.742857 & 2.457143 & 10.00 \\
\hline 7 & 11 & 0.714286 & 1 & 0.5 & 1.857143 & 3.071429 & 12.00 \\
\hline 8 & 94 & 0.4 & 1 & 0.08 & 0.8 & 1.72 & 25.00 \\
\hline 9 & 7 & 0.964286 & 1 & 0.928571 & 1.178571 & 3.071429 & 7.00 \\
\hline 10 & 42 & 0.964286 & 1 & 0.803571 & 0.928571 & 3.446429 & 6.00 \\
\hline 11 & 54 & 0.666667 & 1 & 0.098765 & 1.049383 & 2.123457 & 13.00 \\
\hline 12 & 60 & 0.635294 & 1 & 0.435294 & 0.611765 & 2.023529 & 13.00 \\
\hline 13 & 46 & 0.839286 & 1 & 0.928571 & 1.303571 & 3.071429 & 9.00 \\
\hline 14 & 41 & 0.839286 & 1 & 0.142857 & 1.589286 & 3.571429 & 9.00 \\
\hline 15 & 38 & 0.606061 & 1 & 0.272727 & 1.575758 & 2.606061 & 15.00 \\
\hline 16 & 114 & 0.657465 & 1 & 0.337516 & 1.012547 & 2.513174 & 13.00 \\
\hline 17 & 75 & 0.682236 & 1 & 0.595188 & 1.193914 & 2.756546 & 12.00 \\
\hline 18 & 78 & 0.682236 & 1 & 0.252654 & 1.38075 & 2.912243 & 13.00 \\
\hline 19 & 79 & 0.590325 & 1 & 0.218616 & 1.194734 & 2.385181 & 15.00 \\
\hline 20 & 70 & 0.682236 & 1 & 0.252654 & 1.318471 & 2.974522 & 12.00 \\
\hline 21 & 80 & 0.682236 & 1 & 0.408351 & 1.38075 & 2.756546 & 12.00 \\
\hline 22 & 14 & 0.964286 & 1 & 0.25 & 1.857143 & 3.071429 & 7.00 \\
\hline 23 & 101 & 0.526316 & 1 & 0.105263 & 1.368421 & 2.263158 & 18.00 \\
\hline 24 & 112 & 0.771429 & 1 & 0.742857 & 0.742857 & 2.457143 & 10.43 \\
\hline 25 & 92 & 0.714286 & 1 & 0.142857 & 1.714286 & 3.571429 & 13.00 \\
\hline 26 & 69 & 0.657465 & 1 & 0.337516 & 1.012547 & 2.513174 & 15.00 \\
\hline 27 & 88 & 0.560139 & 1 & 0.488669 & 0.801278 & 2.263219 & 19.00 \\
\hline 28 & 55 & 0.47 & 1 & 0.08 & 0.73 & 1.72 & 27.00 \\
\hline
\end{tabular}

Source: Orji, Anya and Ngwu (2020). $A v \cdot f_{c}=$ Average compressive strength results

Table 4: (5, 2) Design Matrix Components in Real Ratios and the Average Static Modulus of Elasticity

\begin{tabular}{|l|l|l|l|l|l|l|c|}
\hline $\begin{array}{c}\text { Run } \\
\text { Order }\end{array}$ & $\begin{array}{c}\text { Std } \\
\text { Order }\end{array}$ & Water & Cement & \multicolumn{1}{|c|}{ Laterite } & $\begin{array}{c}\text { Quarry } \\
\text { Dust }\end{array}$ & $\begin{array}{c}\text { Coarse } \\
\text { Aggregate }\end{array}$ & Av. $\boldsymbol{E}_{\boldsymbol{s}}(\boldsymbol{G P a})$ \\
\hline 1 & 93 & 0.964286 & 1 & 0.142857 & 1.464286 & 3.571429 & 17.5203 \\
\hline 2 & 105 & 0.964286 & 1 & 0.25 & 1.857143 & 3.071429 & 16.6962 \\
\hline 3 & 10 & 0.526316 & 1 & 0.105263 & 1.368421 & 2.263158 & 25.6015 \\
\hline 4 & 6 & 0.714286 & 1 & 0.928571 & 1.428571 & 3.071429 & 21.5389 \\
\hline 5 & 1 & 0.714286 & 1 & 0.142857 & 1.714286 & 3.571429 & 20.8565 \\
\hline 6 & 21 & 0.771429 & 1 & 0.742857 & 0.742857 & 2.457143 & 18.9173 \\
\hline 7 & 11 & 0.714286 & 1 & 0.5 & 1.857143 & 3.071429 & 21.2302 \\
\hline 8 & 94 & 0.4 & 1 & 0.08 & 0.8 & 1.72 & 27.3292 \\
\hline 9 & 7 & 0.964286 & 1 & 0.928571 & 1.178571 & 3.071429 & 16.1139 \\
\hline 10 & 42 & 0.964286 & 1 & 0.803571 & 0.928571 & 3.446429 & 15.8961 \\
\hline 11 & 54 & 0.666667 & 1 & 0.098765 & 1.049383 & 2.123457 & 20.7359 \\
\hline 12 & 60 & 0.635294 & 1 & 0.435294 & 0.611765 & 2.023529 & 20.0373 \\
\hline 13 & 46 & 0.839286 & 1 & 0.928571 & 1.303571 & 3.071429 & 18.2520 \\
\hline 14 & 41 & 0.839286 & 1 & 0.142857 & 1.589286 & 3.571429 & 19.5851 \\
\hline 15 & 38 & 0.606061 & 1 & 0.272727 & 1.575758 & 2.606061 & 23.0891 \\
\hline 16 & 114 & 0.657465 & 1 & 0.337516 & 1.012547 & 2.513174 & 20.7691 \\
\hline 17 & 75 & 0.682236 & 1 & 0.595188 & 1.193914 & 2.756546 & 20.3520 \\
\hline 18 & 78 & 0.682236 & 1 & 0.252654 & 1.38075 & 2.912243 & 21.5941 \\
\hline
\end{tabular}


International Journal of Engineering Research And Advanced Technology, Vol.7 (5), May -2021

\begin{tabular}{|l|l|l|l|l|l|l|l|}
\hline 19 & 79 & 0.590325 & 1 & 0.218616 & 1.194734 & 2.385181 & 22.0382 \\
\hline 20 & 70 & 0.682236 & 1 & 0.252654 & 1.318471 & 2.974522 & 20.3670 \\
\hline 21 & 80 & 0.682236 & 1 & 0.408351 & 1.38075 & 2.756546 & 20.1531 \\
\hline 22 & 14 & 0.964286 & 1 & 0.25 & 1.857143 & 3.071429 & 16.1454 \\
\hline 23 & 101 & 0.526316 & 1 & 0.105263 & 1.368421 & 2.263158 & 24.2847 \\
\hline 24 & 112 & 0.771429 & 1 & 0.742857 & 0.742857 & 2.457143 & 18.6847 \\
\hline 25 & 92 & 0.714286 & 1 & 0.142857 & 1.714286 & 3.571429 & 21.7687 \\
\hline 26 & 69 & 0.657465 & 1 & 0.337516 & 1.012547 & 2.513174 & 22.6713 \\
\hline 27 & 88 & 0.560139 & 1 & 0.488669 & 0.801278 & 2.263219 & 24.2987 \\
\hline 28 & 55 & 0.47 & 1 & 0.08 & 0.73 & 1.72 & 28.1363 \\
\hline
\end{tabular}

Legend: $A v \cdot E_{s}=$ Average Static modulus of elasticity.

A second degree polynomial (model) was fitted to the static modulus of elasticity data in Table 4 at $95 \%$ confidence limit $(a=0.05)$. The estimated regression coefficient and the analysis of variance (Anova) are shown in Tables 5 and 6 respectively while the normal probability plot of the residual is shown in Figure 1. Taking $X_{1}, X_{2}, X_{3}, X_{4}$ and $X_{5}$ as the proportion of the constituents and $\beta_{1}, \beta_{2}, \beta_{3,} \beta_{4}$ and $\beta_{5}$ as the coefficient of the constituents in relation to Equation 4 , water $=-106.9 X_{1}$, cement $=$ $91.5 X_{2}$, Laterite $=19.0 X_{3}$, Quarry dust $=23.9 X_{4}$, and Coarse aggregate $=26.4 X_{5}$. Therefore, the model equation for static modulus of elasticity is given as;

$E_{s}=-106.9 X_{1}+91.5 X_{2}+19.0 X_{3}+23.9 X_{4}+26.4 X_{5}$

Table 5: Estimated Regression Coefficients for Static modulus of elasticity (component proportions)

\begin{tabular}{lrrrrr}
\hline Term & Coef & SE Coef & T & P & VIF \\
\hline Water & -106.9 & 11.564 & $*$ & $*$ & 72.494 \\
Cement & 91.5 & 4.524 & $*$ & $*$ & 23.839 \\
Laterite & 19.0 & 4.851 & $*$ & $*$ & 5.082 \\
Quarry dust & 23.9 & 4.517 & $*$ & $*$ & 34.976 \\
Coarse Agg & 26.4 & 4.032 & $*$ & $*$ & 129.108 \\
\hline
\end{tabular}

$\mathrm{S}=0.843585 \quad$ PRESS $=25.5244$

$\begin{array}{lll}\mathrm{R}-\mathrm{Sq}=93.91 \% & \mathrm{R}-\mathrm{Sq}(\mathrm{pred})=90.51 \% & \mathrm{R}-\mathrm{Sq}(\operatorname{adj})=92.86 \%\end{array}$

Regression Output

Table 6: Analysis of Variance for Static Modulus of Elasticity (component proportions)

\begin{tabular}{lcccccc}
\hline Source & DF & Seq SS & Adj SS & Adj MS & F & \multicolumn{1}{c}{ P } \\
\hline Regression & 4 & 252.569 & 252.569 & 63.1423 & 88.73 & 0.000 \\
$\quad$ Linear & 4 & 252.569 & 252.569 & 63.1423 & 88.73 & 0.000 \\
Residual Error & 23 & 16.368 & 16.368 & 0.7116 & & \\
Lack-of-Fit & 18 & 13.097 & 13.097 & 0.7276 & 1.11 & 0.497 \\
Pure Error & 5 & 3.271 & 3.271 & 0.6542 & & \\
Total & 27 & 268.937 & & & & \\
\hline
\end{tabular}

Regression Output

The $p$-significant value is less than 0.05 level of significance $(p=0.000, p<0.05), \mathrm{f}=88.73$ ) and the normal probability plot in Figure 1 show that the residuals fall reasonably close to the reference lines. Therefore, the conclusion is that Equation (7) is adequate for predicting the $28^{\text {th }}$ day static modulus of elasticity of laterite-quarry dust concrete. 
International Journal of Engineering Research And Advanced Technology, Vol.7 (5), May -2021

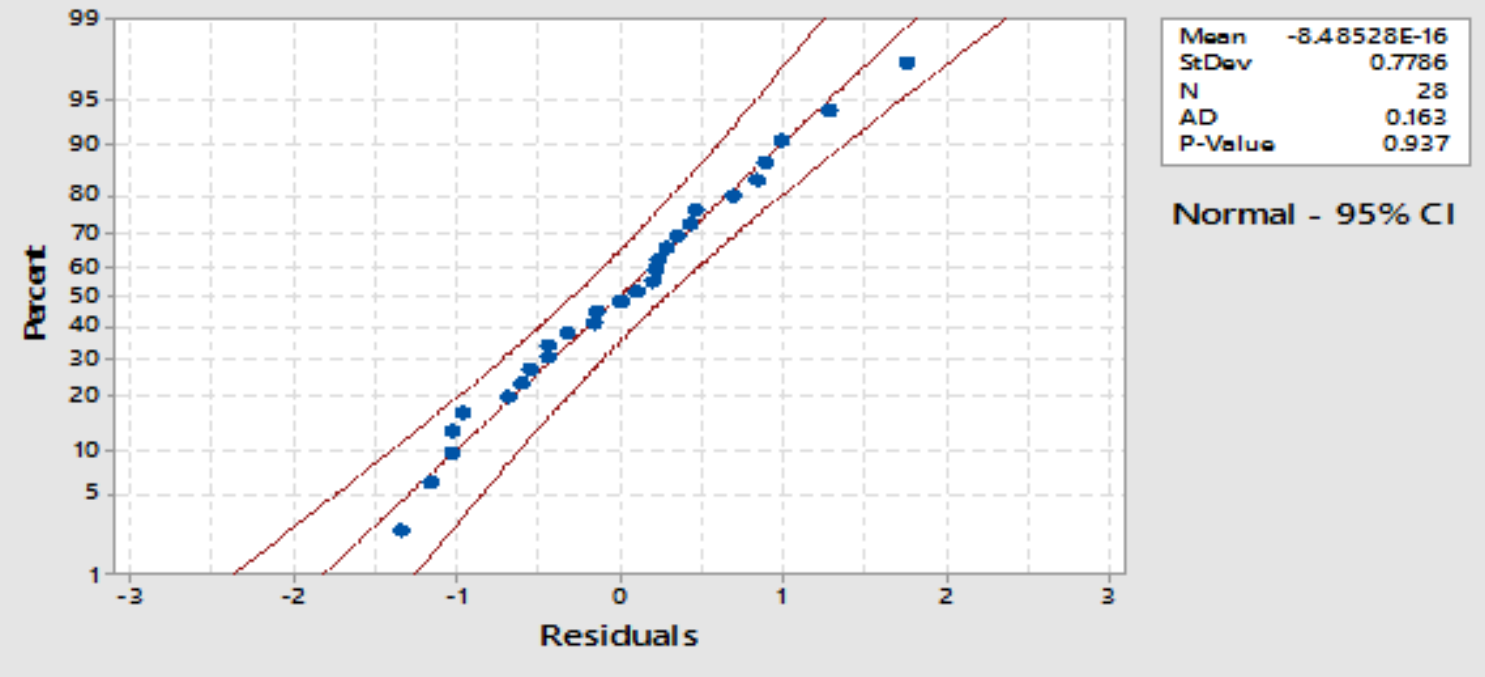

Figure 1: Normal probability plot for static modulus of elasticity residual.

Several mix proportions were generated and converted to ratios in Table 7 . The static modulus of elasticity of the mixes were obtained using the developed model.

Table 7: Static Modulus of Elasticity of Laterite-Quarry Dust Concrete for Several Mix Ratios

\begin{tabular}{|c|c|c|c|c|c|}
\hline \multicolumn{5}{|c|}{ Components in Real Ratios } & \multirow{2}{*}{$\begin{array}{c}E_{s} \\
(G P a)\end{array}$} \\
\hline Water & Cement & Laterite & $\begin{array}{c}\text { Quarry } \\
\text { Dust }\end{array}$ & $\begin{array}{c}\text { Coarse } \\
\text { Aggregate }\end{array}$ & \\
\hline 0.68 & 1 & 0.6 & 0.98 & 2.97 & 21.15 \\
\hline 0.53 & 1 & 0.11 & 1.37 & 2.26 & 24.64 \\
\hline 0.66 & 1 & 0.34 & 1.01 & 2.51 & 21.41 \\
\hline 0.71 & 1 & 0.54 & 0.88 & 2.49 & 19.96 \\
\hline 0.54 & 1 & 0.08 & 0.52 & 1.86 & 24.21 \\
\hline 0.54 & 1 & 0.08 & 0.66 & 1.72 & 24.12 \\
\hline 0.4 & 1 & 0.08 & 0.66 & 1.86 & 28.78 \\
\hline 0.51 & 1 & 0.19 & 0.73 & 2.22 & 25.14 \\
\hline 0.67 & 1 & 0.1 & 1.05 & 2.12 & 20.91 \\
\hline 0.71 & 1 & 0.93 & 1.43 & 3.07 & 20.72 \\
\hline 0.68 & 1 & 0.6 & 1.19 & 2.76 & 21.06 \\
\hline 0.79 & 1 & 0.25 & 1.38 & 2.8 & 19.06 \\
\hline 0.77 & 1 & 0.74 & 0.74 & 2.46 & 18.51 \\
\hline 0.51 & 1 & 0.19 & 0.89 & 2.05 & 25.05 \\
\hline 0.64 & 1 & 0.2 & 0.79 & 2.41 & 21.67 \\
\hline 0.47 & 1 & 0.08 & 0.73 & 1.72 & 26.41 \\
\hline 0.64 & 1 & 0.44 & 0.61 & 2.02 & 21.23 \\
\hline 0.43 & 1 & 0.48 & 0.57 & 1.87 & 26.90 \\
\hline 0.4 & 1 & 0.22 & 0.52 & 1.86 & 28.61 \\
\hline 0.68 & 1 & 0.25 & 1.38 & 2.91 & 21.40 \\
\hline 0.47 & 1 & 0.08 & 0.52 & 1.93 & 26.54 \\
\hline 0.71 & 1 & 0.5 & 1.86 & 3.07 & 21.02 \\
\hline 0.59 & 1 & 0.19 & 0.73 & 2.13 & 22.81 \\
\hline 0.71 & 1 & 0.14 & 1.79 & 3.5 & 21.41 \\
\hline 0.54 & 1 & 0.15 & 0.52 & 1.79 & 24.08 \\
\hline 0.56 & 1 & 0.49 & 0.8 & 2.26 & 23.43 \\
\hline 0.57 & 1 & 0.74 & 0.94 & 2.46 & 23.09 \\
\hline 0.68 & 1 & 0.12 & 1.51 & 2.49 & 21.17 \\
\hline 0.71 & 1 & 0.54 & 1.32 & 3.57 & 21.17 \\
\hline 0.63 & 1 & 0.09 & 0.6 & 2.33 & 21.93 \\
\hline
\end{tabular}


International Journal of Engineering Research And Advanced Technology, Vol.7 (5), May -2021

\begin{tabular}{|c|c|c|c|c|c|}
\hline 0.4 & 1 & 0.08 & 0.8 & 1.72 & 28.70 \\
\hline 0.71 & 1 & 0.93 & 0.93 & 3.57 & 20.90 \\
\hline 0.47 & 1 & 0.29 & 0.52 & 1.72 & 26.15 \\
\hline 0.59 & 1 & 0.22 & 1.19 & 2.39 & 23.02 \\
\hline 0.54 & 1 & 0.22 & 0.52 & 1.72 & 23.95 \\
\hline 0.79 & 1 & 0.6 & 1.08 & 2.76 & 18.78 \\
\hline 0.54 & 1 & 0.15 & 0.59 & 1.72 & 24.03 \\
\hline 0.61 & 1 & 0.68 & 0.68 & 2.23 & 21.98 \\
\hline 0.68 & 1 & 0.25 & 1.32 & 2.97 & 21.42 \\
\hline 0.79 & 1 & 0.25 & 1.21 & 2.97 & 19.13 \\
\hline 0.76 & 1 & 0.32 & 0.73 & 2.82 & 19.21 \\
\hline 0.76 & 1 & 0.11 & 0.94 & 2.82 & 19.39 \\
\hline 0.59 & 1 & 0.27 & 0.73 & 2.05 & 22.68 \\
\hline 0.58 & 1 & 0.09 & 0.56 & 2.08 & 23.07 \\
\hline 0.4 & 1 & 0.08 & 0.52 & 2 & 28.87 \\
\hline 0.48 & 1 & 0.62 & 0.62 & 2.05 & 25.45 \\
\hline 0.71 & 1 & 0.14 & 1.71 & 3.57 & 21.44 \\
\hline 0.71 & 1 & 0.32 & 1.86 & 3.25 & 21.20 \\
\hline 0.51 & 1 & 0.35 & 0.73 & 2.05 & 24.88 \\
\hline 0.71 & 1 & 0.93 & 1.18 & 3.32 & 20.81 \\
\hline 0.51 & 1 & 0.09 & 0.56 & 2.15 & 25.40 \\
\hline 0.59 & 1 & 0.19 & 0.81 & 2.05 & 22.76 \\
\hline 0.51 & 1 & 0.38 & 0.67 & 2.56 & 24.88 \\
\hline 0.61 & 1 & 0.12 & 1.58 & 2.76 & 23.01 \\
\hline 0.71 & 1 & 0.71 & 1.64 & 3.07 & 20.87 \\
\hline 0.51 & 1 & 0.1 & 0.95 & 2.56 & 25.15 \\
\hline 0.61 & 1 & 0.27 & 1.58 & 2.61 & 22.83 \\
\hline 0.4 & 1 & 0.36 & 0.52 & 1.72 & 28.35 \\
\hline 0.57 & 1 & 0.74 & 0.74 & 2.66 & 23.18 \\
\hline 0.45 & 1 & 0.09 & 1.05 & 1.95 & 26.67 \\
\hline 0.71 & 1 & 0.14 & 1.86 & 3.43 & 21.39 \\
\hline 0.68 & 1 & 0.41 & 1.38 & 2.76 & 21.21 \\
\hline 0.79 & 1 & 0.3 & 1.38 & 2.76 & 19.01 \\
\hline 0.4 & 1 & 0.22 & 0.66 & 1.72 & 28.53 \\
\hline 0.54 & 1 & 0.08 & 0.59 & 1.79 & 24.16 \\
\hline 0.76 & 1 & 0.24 & 1.32 & 2.63 & 19.55 \\
\hline
\end{tabular}

Legend: $E_{s}=$ Statics Modulus of Elasticity.

\section{CONCLUSIONS}

The bulk densities of laterite and quarry dust were found to be $1240 \mathrm{~kg} / \mathrm{m} 3$ and $1695 \mathrm{~kg} / \mathrm{m} 3$. They compared favorably with the bulk densities derived by [13, 18 and 3]. Similarly, the specific gravities were found to be 2.60 and 2.79 . Which also compared favorably with the specific gravities derived by [23, 2 and 19]. The sieve analysis indicated that both laterite and quarry dust falls within zone II of the grading of fine aggregate as given in [9] and they are both suitable for making concrete. Model equations for predicting the static modulus of elasticity of laterite-quarry dust concrete was developed. $\mathrm{X}_{1} \ldots . . \mathrm{X}_{5}$ in the model are the proportions of water, cement, laterite, quarry dust and crushed rock in the mix. The model was tested for it significance using the $\mathrm{p}$-value and $\mathrm{F}$ test statistics and found adequate. The minimum and maximum static modulus of elasticity predictable by the model in Table 7 are $18.51(\mathrm{GPa})$ and $28.87(\mathrm{GPa})$ respectively. This model can be used to predict the static modulus of elasticity of laterite-quarry dust concrete for both domestic and commercial constructions and it will be very beneficial in the reduction of the number of trial mixes, use of arbitrary mixes and cost indeterminacy. In this regard, the use of models for predictions should be encouraged in the construction industry. 


\section{REFERENCES}

[1] Akhnazarova, S., \& Kafarou, V (1982). Experiment optimization in Chemistry and chemical engineering. MIR publishers, Moscon.

[2] Anya, U. C. (2015). Model for Predicting the Structural Characteristics of Sand-Quarry dust Blocks. Ph.D. Thesis, School of Engineering, University of Nigeria, Nsukka, Nigeria.

[3] Anzar, H. M. (2015). Improved concrete properties using quarry dust as replacement for natural sand. International journal of engineering research and development. 11(03), 46-52. www.ijerd.com.

[4] Ata, O., Olusola, K., Omojola, O., \& Olanipekun, A. (2007). Study of compressive strength characteristics of laterite/sand Hollow blocks. Civil engineering dimension. 9(1), 15-18.

[5] British Standard Institution. BS EN 12390-3 (2002): Testing hardened concrete. Compressive strength of test specimens. London.

[6] British Standard Institution. BS EN 1008 (2002): Mixing water for concrete specification for sampling, testing and assessing the suitability of water, including water recovered from processes in the concrete industry, as mixing water for concrete. London.

[7] British Standard Institution. BS EN 12390-1 (2000): Testing hardened concrete. Shape, dimension, and other requirements for specimens and moulds. London.

[8] British Standard Institution. BS EN 12390-4 (2000): Testing hardened concrete. Compressive strength specifications for testing machines. London.

[9] British Standard Institution. BS 882 (1992). Specification for Aggregates from Natural Sources for Concrete. London.

[10] British Standard Institution. BS 1881-121 (1983). Testing concrete. Method for determination of static modulus of elasticity. London.

[11] Cornel, J. (2002). Experiments with mixtures: designs, models and the analysis of mixture data. 3ed. New York, USA, John Wiley and sons Incorporation.

[12] Dongapure, A. R., \& Mangalgi, S. S. (2014). Study on strength of concrete Using laterite sand and quarry dust as fine aggregate. International journal of engineering research and technology. 2014. 3(12).

[13] Duggal, S. K. (2012). Building Materials. $4^{\text {th }}$ edition. New age international Limited Publishers 4835/24, Ansari Road, Daryaganj, New Delhi-110002.

[14] Manasseh, J. (2010). Use of crushed granite fine as replacement to river sand in concrete production, Leonardo electronics journal of practice and technologies. 17, 85-96.

[15] Mehta, P. K., Monteiro, P. J. M. (2008). Concreto: Microestrutura, propriedades e materiais. $3^{\text {rd }}$ ed. Sao Paulo: IBRACON.

[16] Neville, A. M. (2011). Properties of concrete. $5^{\text {th }}$ edition. England: Pearson.

[17] Nigeria Industrial Standard. NIS 444 (2003): Quality Standard for Ordinary Portland cement. Standard Organization of Nigeria.

[18] Okafor, F. O., \& Egbe, E. A. (2016). Structural Properties of Laterite - Quarry dust Cement Blocks. Quest Journals. Journal of Architecture and Civil Engineering. 3(3), 12-17.

[19] Opara, H. E., Eziefula, U. G., \& Eziefula, B. I. (2018). Comparison of physical and mechanical properties of river sand concrete with quarry dust concrete. SSP-journal of civil engineering. Special Issue. 127-134.

[20] Orji, S. E. (2021). Models for predicting the structural properties and cost of concrete using laterite and quarry dust as fine aggregate. Unpublished Ph.D. Thesis Submitted to the Department of Quantity Surveying, Enugu State University of science and technology, Enugu State, Nigeria.

[21] Orji, S. E., Anya, U. C., \& Ngwu, C. (2020). Models for predicting the compressive strength and cost of laterite-quarry dust concrete using extreme vertices design. The international journal of engineering and science (IJES). 9(01) 1-6.

[22] Orji, S. E., Ugwu, I. C., \& Anya, U. C. (2020). Comparison of compressive strength and cost of river sand and model predicted laterite-quarry dust concrete. IOSR journal of mechanical and civil engineering. 17(1), 50-56.

[23] Osuji, O. S., \& Akinwamide, J. T. (2018). Engineering properties of lateritic soils in Ado-Ekiti, South western, Nigeria. American journal of engineering research. 7(1), 353-360.

[24] Otari, L. B., Pereira, A. H. A. (2017). Estimation of the static modulus of elasticity of concrete using impulse excitation technique. Technical report. ATCP. Physical engineering. May, 2017.

[25] Otunyo, A. W., \& Jephter, B. G. (2018). Predictive model for compressive strength of concrete made from recycled concrete coarse aggregates. Nigerian Journal of Technology. 37(3), 633-639.

[26] Prakash, K. S., \& Rao, C. H. (2016a). Study on compressive strength of quarry dust as fine aggregate concrete. Advances in civil engineering. 2016(2016), 1-5.

[27] Prakash, K. S., \& Rao, C. H. (2016b). Strength characteristics of quarry dust in replacement of sand. International conference on advanced material technologies. $27^{\text {th }}$ and $28^{\text {th }}$ December, 2016. Dadi institute of engineering and technology. Visakhapatnam, Andhra Pradesh, India. 
[28] Sabarish, G., Ratnam, M. K. M., Prasad, A. C. S., \& Raju, U. R. (2015). A study on strength and durability characteristics of concrete with partial replacement of fine aggregate by laterite sand. International journal for innovative research in science and technology. 2(03).

[29] Salau, M. A., \& Busari, A. O. (2015). Effect of different coarse aggregate sizes on the strength characteristics of laterized concrete. $2^{\text {nd }}$ international conference on innovative materials, structures and technologies. 10P publishing. Materials science and engineering. 96(2015).

[30] Shuaibu, R. A., Mutuku, R. N., \& Nyomboi, T. (2014). A review of the properties of laterite concrete. International journal of civil and structural engineering. 2014. 5(2).

[31] Zerdi, T. A., Hussain, S. S., Ali, S. Z., \& Ansari, Q. (2016). Suitability of using laterite as partial replacement of fine aggregate in concrete. Indian journal of applied research. IC value: 74.50. 6(5).

Corresponding Author: Orji, Solomon Emeka. soulvic2@yahoo.com 